\title{
Shepard Meets Shakespeare to Speak about "Authenticity": A Comparative Encounter in the "Presence" of Derrida
}

\author{
By Mahdi Shafieyan*
}

\begin{abstract}
Comparative studies reveal the universal nature of human thought. Not only can themes appear as the common trait within two works, but also similitude may disguise itself in characters. In this article, the researcher juxtoposes two brothers form Shakespeare's play, King Lear, with two brothers from Sam Shepard's True West while drawing on the Derridean concept of "authenticity." As a matter of fact, Derrida's concept of "difference" is applied practically; that is, each brother and his counterpart in the other play not only share some similarities but reveal shades of difference as well. Edgar and Edmund are considered in opposition to each other, but Austin and Lee, though seemingly diametric, have streaks of common points, which are reversed at the end of the play. The findings confirm that canonical literary themes can still be considered universal, as a classic play from the seventeenth century by a British writer approximates a dramatic piece from the postmodern era by an American dramaturge. This is of paramount significance since in the Derridean philosophy of literature the universality of literature is questioned. Refuting the "grand narratives" or posing "ideology" in order to indirectly obliterate the difference between literary and literal language, the other postmodern thoughts also adopt the same position.
\end{abstract}

Surveying world literature leads one to the idea that themes are stable but their representations differ; this could be generalized to characters since man innately tends to good and repels evil. This fact is even admitted by the philosophers who question the stability of existence. Although arguing against "the transcendental," hence "the unitary" and "universal," believing that the "literary text [is] radically situated-written and read and re-read at particular times and places-and as possessing a singularity (each time),"1 Jacques Derrida says, "'ideas' ... belong to everyone; [they are] universal in their essence."2 Further, his "trace," which is embedded in postmodern notions such as "intertextuality," in one respect flies in the face of the critical idiom, "ideology," which presumes that a system determines the author's unconscious, so each work is, regionally speaking, wrought in particular. In fact, what do the ideas of "trace" or "intertextuality" indicate but the fact that words and thoughts are shared? They are, in other words, borrowed and lent

* Assistant Professor of English Literature, Faculty of Foreign Languages, Imam Sadiq University, Iran.

1. Derek Attridge, "Introduction: Derrida and the Questioning of Literature," introduction to Acts of Literature, ed. Jacques Derrida (New York: Routledge, 1992), 15.

2. Jacques Derrida, Acts of Literature, ed. Derek Attridge (New York: Routledge, 1992), 314. 
infinitely in a universal economy, metaphorically speaking. This could probably be paraphrased as "singularity" simultaneous with "generality." The significance of this idea for comparative studies might be the emphasis on seeing the differences in the relevant research; that is, one in a comparative study should not wholly focus on the common grounds, but also on where the two appear "different."

This matter could be demonstrated when one compares a drama masterpiece from the seventeenth century, King Lear (1605) by William Shakespeare, ${ }^{3}$ with an important work in the twentieth century, True West (1980) by Sam Shepard, ${ }^{4}$ and detects so many "different" similarities in various aspects of the pieces. This research, however, intends to focus on character building and to collate Edgar and Edmund in the classic work with Austin and Lee in the postmodern one in terms of power relations, which is translated in the Derridean terminology as "authenticity." It is remarkable that the former brothers are among the minor characters, while the latter are the major ones in the main plot.

As all readers may not have read the contemporary play, a succinct summary of its plot sounds inevitable: The set in the mother's house, the play lets us know that two brothers are reconnected after five years. Their mother is on vacation, and their father is on desert, so Austin is house sitting. He is working on his screenplay, yet Lee continually distracts him with irrelevant questions. Austin asks Lee to leave the house because a film producer, Saul, is coming by to negotiate about his screenplay. When Austin and Saul are discussing their agreement, Lee enters with a stolen television. Little by little, Lee attracts Saul, taking about playing golf and proposing a script idea. Then, Austin asks Lee for his car keys back, and Lee assumes this as an attempt to make him leave, but Lee says he cannot be kicked out. In the next act, Lee tells Austin that Saul has promised him an advance for his idea and has dropped Austin's screenplay. He expects Austin to write the screenplay, yet he thinks that Lee's story is illegitimate and unreal. The next scene opens when Austin is cleaning the toasters he has stolen, while Lee is twiddling with a typewriter. They make a deal that Lee will take him to the desert if Austin writes the play for Lee. In the final scene, after an argument, Austin tries to strangle Lee, but gets worried that he has killed his brother. As he moves toward the door, Lee rises in front of him.

Concerning the background research of this paper, one can only find the works that have taken the characters of each play separately as the biblical representations; that is to say, in both dramatic pieces, there is animosity of

3. William Shakespeare, The Tragedy of King Lear, ed. Jay L. Halio (Cambridge: Cambridge University Press, 2005).

4. Sam Shepard, True West. The Bedford Introduction to Drama, ed. Lee A. Jacobus (New York: St. Martin's, 2001). 
some kind between the two brothers included, which reminds us of Abel and Cain. We are exposed to this archetype, ${ }^{5,6}$ when Lee and Austin say,

AUSTIN. You're my brother.

LEE. That doesn't mean a thing. You go down to the L. A. Police Department there and ask them what kind' people kill each other the most. What do you think they'd say?

AUSTIN. Who said anything about killing?

LEE. Family people. Brothers. (1.4)

This comparative point adds to the previous pieces of proof suggesting the universality of impressions and the focus on the similarities in comparative studies. In the present study, nonetheless, the differences between the two pairs of brothers would also be brought to light; even their similarities, which are mostly highlighted, bear streaks of "alterity." I compare Edmund with Lee (Cain figures) and Edgar with Austin (Abel figures) so as to underline such examples of identity leakage.

\section{Argument}

Shepard's play, unlike its classic antecedent starting with dramatis personae, begins with the description or representation of the two brothers, whose differences in appearance foreshadow their apparent distinct natures:

AUSTIN, early thirty, light blue shirt, light tan cardigan sweater, clean blue jeans, white tennis shoes

LEE, his older brother, early forties, filthy white t-shirt, tattered brown overcoat covered with dust, dark blue baggy pants from the Salvation Army, pink suede belt, pointed black forties dress shoes scuffed up, holes in the soles, no socks, no hat, long pronounced sideburns, "Gene Vincent" hairdo, two days' growth of beard, bad teeth. $(1368)^{7}$

As we see, longer lines and descriptions are used for Lee, and this is the case with Edmund too, implying that they are more under the two writers' magnifying glass than their brothers. Hence, in this article most of the points

5. Stephen James Bottoms, The Theatre of Sam Shepard: States of Crisis (Cambridge: Cambridge University Press, 2000), 11.

6. Harold Bloom, Sam Shepard (New York: Infobase, 2009), 77.

7. As in contemporary plays it is not common to have line number, I have provided my readers with the page number from the edition I have read, then the act and the scene number. 
are about the comparison between Edmund and Lee since they own a greater textual share in the plays.

Here, readers are informed of the best and worst appearances attributed to Austin and Lee respectively. Although Samuel Taylor Coleridge favored and examined the role of Edmund by his appearance, saying: "From the first drawing up of the curtain Edmund has stood before us in the united strength and beauty of the earliest manhood," 8 in Shakespeare's one understands the characters' nature by what they reveal verbally, rather than by their semblance. However we assume, Edmund's counterpart, Lee, does not have such beauty of appearance; indeed, it is Austin who is very fashionable.

As the first feature, reptilian movement in power is a trait shared by Lee and Edmund. Lee in his words first tries to show a kind of equality to Austin: "I mean she's my mother too, right?" (1369; 1.1). But then he carries a sense of superiority which will be investigated later. Edmund also primarily deludes his legitimate brother, Edgar, of his land; then he usurps his father's earldom, and finally makes an attempt on the English crown itself by bedding Lear's two daughters Regan and Goneril.

From the very beginning, it is Lee who comes to power; although later it becomes clear that he is a thief and so of a lower rank in comparison to his writer-brother, he is the one who asks questions like a detective:

LEE. So, Mom took off for Alaska, huh?

AUSTIN. Yeah.

...

LEE. You keepin' the plants watered?

AUSTIN. Yeah.

LEE. You got coffee?

AUSTIN. Yeah. $(1368-9 ; 1.1)$

From these few lines, we find Austin with his short answers as a yes-man to his thief-boss. Lee's questions along with "Sorta' left you in charge" or "Kinda' nice for you, huh? Whole place to yourself?" (1368; 1.1, emphasis added) raise the matters of authenticity and puissance. Austin, too, in response to the last question says, "Yeah, it's great." Indeed, he is Mom's trustworthy son, in opposition to Lee, a thief, whose job obliterates the question of authenticity. Their closeness to one parent and distance from the other one, as a matter of fact, defines their degree of authority. Both works express a division between not only brothers but also the father and the sons; nonetheless, in the renaissance play nearness to the father and farness from the mother (of

8. Samuel Taylor Coleridge, "Notes on King Lear" (1819), Literary Remains, ed. Henry Nelson Coleridge. Vol. 2 (London: Pickering, 1836), 189. 
Edmund) is of importance, while in the contemporary one the reverse case is appreciated; Lee's distance from home and his mother, two symbols of love, suggests his status as an ostracized child.

Yet, power relations change when the excluded one is favored by an influential person; as such, the character who finds power, in essence, becomes like the authentic coin and the other like the fake one. In Lee's case, when chosen by Saul Kimmer, he says, "I'm a screenwriter now! I'm legitimate" (1381; 2.7, emphasis added). This is comparable to the question of legitimacy in Shakespeare's play. In fact, conflict arises when Edmund is motivated by his desire to overcome his own illegitimacy. ${ }^{9}$

The verbal brevity of Austin and Edgar in opposition to the verbiage of Lee and Edmund represents the latter pair as men of words, those who know verbal management, the characters have found the power of language and are able to mine their linguistic treasure, although Edmund as a classic character, exemplified below, knows how to wrap his words with nice ribbons better than Lee does as a modern man suffering from bad-mouthing and poor grammar: "he musta' be lyin'" $(1378 ; 2.5)$, or "That don't make any difference though does it?" (1374; 1.3).

The next point of similarity is confidence, which is the consciousness of one's powers; Lee from the outset shows up as a confident man in the domain of an unconfident, though authorized, brother:

AUSTIN. Help yourself to whatever's - (Motions to refrigerator.)

LEE. I will. Don't worry about me. I'm not the one to worry about. I mean I can uh. $(1369 ; 1.1)$

Lee's claim of being able to write "art" that "was ahead of its time" (1369; 1.1) adds emphasis to the given point. His way of speaking laden with much self-assurance arouses laughter in the audience when they see a thief is speaking about art, even claiming to do better than his writer-brother. Edmund is, likewise, an Iago-figure, playful, confident, but never jovial; in effect, it was Edgar who played the fool in many ways, when he donned his Poor-Tom disguise. ${ }^{10}$

When Lee replies, "I will. Don't worry about me" to the above-mentioned sentence by Austin, we see his intent to usurp his brother's territory. Some minutes later when Austin says, "Well, you can stay here as long as I'm here," he immediately reacts, "I don't need your permission do I?" (1369; 1.1). This is very much like Edmund's intention to get not only his brother's land but his father's position.

9. Jeffrey Kahan, King Lear: New Critical Essays (New York: Routledge, 2008), 16. 10. Ibid., 73. 
Although Jeffrey Kahan believes that Lear, Gloucester, and the Duke of Albany stand in the feudal order and on the other hand Goneril, Regan, Edmund, and Cornwall are the individualists who have the characteristic outlook of the bourgeoisie, ${ }^{11}$ Edmund is, characteristically, clear-sighted about land as a source of social and economic status. ${ }^{12}$ His emphasis falls on "fortunes," in the sense of inherited wealth (1.2.46), and, repeatedly, "revenue" $(1.2 .51,53,67)$. Personal wealth, not some quaint notion of the duties of vassalage, informs Edmund's understanding of the meaning and value of land: hence, his famous lines in Act 1, Scene 2: "Legitimate Edgar, I must have your land,"13 and "Let me, if not by birth, have lands by wit."14 His name, "Edmund," itself means "protector of possession," in contrast to "Edgar" which per se signifies "riches." ${ }^{15}$ While Austin lives in a city, Lee and his father live on a desert or land as well. His job, heist, also represents his stress on property: "Buy him [their father] off with yer Hollywood blood money, but not me! I can git my own money my own way. Big money!" (1370; 1.1).

In line with power relations, Harold Bloom holds the opinion that Edmund is a pragmatist. ${ }^{16} \mathrm{He}$ does not believe in fixed authority, and is contemptuous of his father's explanation of change to be found in the sun and the moon. He does not disagree with Gloucester that all of these changes are happening, but he has a different set of reasons to account for them: "This is the excellent foppery of the world, that when we are sick in fortune, often the surfeits of our own behaviour, we make guilty of our disasters the sun, the moon, and the stars" (1.2.104-6). This clash demonstrates that Lear and his friends, Gloucester, Edgar, and Kent, continue to see the world in an "oldfashioned" way. ${ }^{17}$

We are now familiar enough with Lee to say that he fits in this pragmatic picture, yet the representation of Austin is very romantic; we look at the description of his sitting place: "Candlelight appears in alcove illuminating Austin is seated at a glass table hunched over a writing notebook, pen in hand, cigarette burning in ashtray, cup of coffee, typewriter on table, stacks of paper, candle burning on table" $(1368 ; 1.1)$.

11. Ibid., 63.

12. Ania Loomba, \& Martin Orkin, Post-Colonial Shakespeares (London: Routledge, 2004), 209.

13. Kahan, King Lear: New Critical Essays, 16.

14. Ibid., 155.

15. William Morris, The American Heritage Dictionary (Boston: Houghton, 1972), 414-415.

16. Harold Bloom, William Shakespeare's King Lear: Bloom's Notes (Chelsea: Chelsea, 1996), 42.

17. Paul Corrigan, Shakespeare on Management: Leadership Lessons for Today's Managers (London: Kogan Page, 1999), 67. 
Authorship is another critical subcategory in power relations. Showing the paradoxical nature of language, Edmund's letter and Lee's script, as writings, from a philosophical perspective do not seem reliable. ${ }^{18}$ What Edmund shows as Edgar's letter is not his but his own handwriting and Lee's script that convinces Saul to produce it in Hollywood has also been written by Austin. In both cases, in fact, the person who is claimed/claims to be the author is not; that is to say, Edmund and Lee are both conspirators who by a written text try to achieve their goals. Bloom agrees on the argument, saying: "Shakespeare uses the word letter thirty-three times in Lear. No other tragedy comes close in such frequency. Interestingly, the use of the word letter corresponds exactly with the frequency of the word nothing, which also appears thirty-three times." 19 Letters are indirect in being speech reduced to signs; that is, they can only offer indirect, mediated discourse, not reality. In this regard, texts may seem deadly, as in King Lear we see that letters bring or intend death, and in the case of Austin and Lee, when the latter's script is accepted by Saul, he faces his brother's fists. In this way, the matter of authenticity is concatenated with representations; in other words, representation is used to produce authenticity.

Lee is strongly introduced as a man of representation: he steals TVs, an appliance for shows; he attracts Saul the producer in Hollywood, which is again the place of representations; he knows how to act out a role in order to undermine his brother, as the number of his sentences during the conversation with Kimmer is four times more than Austin's, to name a few instances. Lee understands that in a world of representations he should have his feet on the ground (land). Edmund, as well, has studied acting; he knows how to manage the situation in which he claims Edgar's treachery. First, he holds a letter he has just written as if it is Edgar's; when he sees that his father is coming, in a show he puts the letter in his pocket making sure that Gloucester saw this action (1.2.27-103). Then, coming to Edgar he says,

I hear my father coming. Pardon me,

In cunning, I must draw my sword upon you.

Draw, seem to defend yourself. Now, quit you well.

[Shouting] Yield! Come before my father! - Light ho, here! -

Fly, brother! - Torches, torches! - so, farewell.

[Exit Edgar]

Some blood drawn on me would beget opinion

18. Derrida averred that in the Western metaphysics, "from Plato to Rousseau, Descartes to Husserl" writing had been understated for its inability to bear and transfer meaning (Jacques Derrida, Limited Inc., trans. Samuel Weber and Jeffrey Mehlman (Evanston: Northwestern University Press, 1988), 93.

19. Bloom, William Shakespeare's King Lear:, 75. 
Of my more fierce endeavour.

[Wounds his arm]

...

Father, father!

Stop, stop! No help? (2.1.28-36)

In this scene, Gloucester says, "of my land, / Loyal and natural boy, I'll work the means / To make thee capable" (2.1.82-4). Labeled as "loyal," Edmund also becomes his father's "beloved" and trustee, the necessary features to be authentic, when Gloucester says about Edgar, "[he] is no dearer in my account [than Edmund]" (1.1.16). Lee, in a like vein, has lived for a while with his father on the land; however, he makes clear that "I was on my way to see the old man." Then Austin questions, "You mean you just passed through there?" to which Lee responds, "That's right" (1371; 1.2). In both cases, therefore, we have the fraudulent representation of loyalty.

As mentioned above, Edmund is a perfect schemer, a Machiavellian personality avid to grasp any opportunity and ready to do anything to attain his goals, yet his ambition reflects not only a thirst for land (power) but also the desire to be recognized, as he is a bastard. He, early in the play, resolves to get rid of Edgar, then his father, in order to become Earl in his own right. Later, he flirts with both Regan as well as Goneril and makes an effort to play them off against each other. Indeed, he is more wicked than Lee since the latter just directs his revenge at Austin, the revenge which is probably not a villainous act but to show that his capabilities overweigh Austin's.

Edgar, the legitimate son and heir, will inherit all of Gloucester's property. Edmund realizes that the law denying the father's property to the illegitimate son is merely a "custom," something that through representation has become prevalent among people, so authentic:

Thou, Nature, art my goddess; to thy law My services are bound. Wherefore should I

Stand in the plague of custom and permit

The curiosity of nations to deprive me?

For that I am some twelve or fourteen moonshines

Lag of a brother? Why "bastard"? Wherefore "base"? (1.2.1-6, emphasis added)

It is a man-made rule; he is just as much a man as is his brother. Why, then, should bastards be regarded as inferior people? From a postmodern perspective, the rules or "genres" are some conventions which may leak. It is here that authority finds an extricable tie to representation. Sean McEvoy comments that "rationally speaking, one can see the truth of what he says. His father's affection for him is the same as it is for Edgar (1.2.17-18). Thus, Edmund has seen that the relationship between affection and property is 
purely arbitrary."20 Lee similarly breaks laws: As a burglar, he violates the established rules and at the same time justifies his action when Austin criticizes him for robbery, saying: "They don't need their televisions! I'm doin' them a service" $(1376 ; 2.4)$. While Edmund comes to refute his nature, Lee confesses that his posturing pride in his lower-class status is simply a front for a deep-rooted sense of failure and helplessness: "I'm livin' out there [on the desert] "cause I can't make it here" $(1385 ; 2.8)$.

To refer to another instance, Edmund holds the belief that if our natures were laid down by the position of the stars in the sky at the moment of our conception, we could do nothing to change the way the world is. In that sense, astrology would be a part of a distinctly conservative ideology. Nevertheless, he sees this as a story people tell to mask the reality, like the one about "illegitimacy," in order to be able to exert power over others. Edmund sees the fact that justice in the world of the play is simply what the powerful say. ${ }^{21}$ In True West, Lee perceives that it is Kimmer, as a rich producer, ${ }^{22}$ hence powerful, who decides which play is fit for production; although Kimmer is unjust that Lee's script is better, his power speak. In turn, Lee, vested with the producer's trust, like a literary critic, comments on "his" play's reality, which is not assumed so by Austin:

AUSTIN. It's not like real life! It's not enough like real life. Things don't happen like that.

LEE. What! Men don't fuck other men's women?

AUSTIN. Yes. But they don't end up chasing each other across the Panhandle. Through "Tornado Country."

LEE. They do in this movie!

AUSTIN. And they don't have horses conveniently along with them when they run out of gas! And they don't run out of gas either.

LEE. These guys run outa' gas! This is my story and one a "these guys runs outa" gas! (1375; 1.4., emphasis added)

As Edmund demonstrates, however, an understanding of how ideology works does not seem to lead to any desire to make the world a fairer place. ${ }^{23}$ It

20. Sean McEvoy, Shakespeare: The Basics (London: Routledge, 2000), 195-196.

21. Ibid., 197.

22. It is also the predominant characteristic of postmodern societies that are dominated by "economy" or money, the most salient feature of which is its nonexistence; it is only a symbol or an idea in people's minds, as opposed to a physical object one could touch. It is, in short, an image that has occupied the status of reality, a representation that leads to ideology (David Hawkes, Ideology, 2nd ed. (London: Routledge, 2003), 17).

23. Jonathan Dollimore, Radical Tragedy: Religion, Ideology and Power in the Drama of Shakespeare and His Contemporaries (Brighton: Harvester Wheatsheaf, 1984), 201. 
should be pointed out that Machiavelli also believed that "the Prince," his ideal ruler, had a right to rule because the mass of his subjects lacked the intelligence and virtue to ensure the general good. ${ }^{24}$ We remember again the famous line by Edmund emphasizing his smartness: "Let me, if not by birth, have lands by wit" (1.2.155) because "[I have a] credulous father and a brother noble ... on whose foolish honesty/My practices ride easy" (1.2.151-4). Lee also underlines the issue of intelligence so many times in the Shepardian drama: "You think yer the only one in the brain department here? ... There's other people got ideas too, ya' know!" Moreover, when his brother speaks about the urban people's trickery, he carries on,

They can't touch me anyway. They can't put a finger on me. ... I can come in through the window and go out through the door. They never knew what hit "em. You, yer stuck. Yer the one that's stuck. Not me. So don't be warnin" me what to do in this town. (1378-9; 2.5)

Up till now, as seen, Shakespeare's drama demarcates the "good" child from the "bad" one and pits the faithless against the dutiful. ${ }^{25}$ However, the case in True West is not as clear-cut as in King Lear; it is not easy to say which brother is the "good" and which one the "bad" for, as mentioned above, toward the end of the play the two brothers interchange their positions. True West examines what Shepard has called "double nature," the ongoing clash of good and bad, male and female in a single individual. ${ }^{26}$ Lee at the beginning is drunk but at the end rational, and the reversed case applies to Austin. They, in fact, are one person: Austin says that Saul "thinks we're the same person" (1381; 2.7). This "double" pairing of Lee and Austin represents the different sides of the writer's own consciousness, or an author's imagination and craftsmanship. ${ }^{27}$ To prove this, we can say that as the imagination can work nonstop, Lee may never sleep $(1370 ; 1.1)$ and should go burglarizing. William Kleb suggests, "Austin represents objectivity, self-control and self-discipline, form and order, the intellect, reason. Lee stands for subjectivity, anarchy, adventure, excess and exaggeration, intuition and imagination." ${ }^{28,29}$ It is here

24. Nicolo Machiavelli, The Prince. trans. W. K. Marriott (Coral World Greatest Books, 1991), 28.

25. Bloom, William Shakespeare's King Lear:, 14.

26. Johan Callens, Sam Shepard: Between the Margin and the Centre (Amsterdam: Overseas, 1998), 74 .

27. Matthew Roudan'e, The Cambridge Companion to Sam Shepard (Cambridge: Cambridge University Press, 2002), 82, 153.

28. William Kleb, "Worse than Being Homeless: True West and the Divided Self," in American Dreams: The Imagination of Sam Shepard ed. Bonnie Marranca (New York: Performing Arts Journal, 1981), 121. 
that once more the alterity or "the state of differences" in comparative studies becomes meaningful.

The brothers switch places as Lee tries to write without the aid of Austin, and Austin lies drunk on the floor; that is, the writer's imagination takes hold of him, driving out the craftsmanship. Later, Lee, who at first claimed that he could write the whole script on his own, begs Austin for help. In other words, imagination cannot create art without the aid of conscious skills. The relationship of the brothers turns into a symbiotic one as both see the inadequacies of their own positions: When Austin agrees to help Lee write the screenplay in exchange for Lee's taking him to the desert, some integration of craft and imagination begins to seem possible, and they do manage to work together. It is here that Derrida's strategy of "overturning" of authority, authenticity, or hierarchy becomes meaningful; that is, there is no simple reversal, but a transformation: "What must occur then is not merely a suppression of all hierarchy, for an-archy only consolidates just as surely the established order of a metaphysical hierarchy; nor is it a simple change or reversal in the terms of any given hierarchy. Rather the Umdrehung must be a transformation of the hierarchical structure itself." 30 In this process, Lee does not show up as the superior and Austin as the inferior, but the former needs the latter whose place is now taken.

In Shakespeare's play, this "double nature" is represented in another way: Edmund who seems very evil has also some good characteristics. His words near death, following his overthrow by Edgar, involve contrition -"This speech of yours hath moved me" (5.2.190)-confession-"What you have charged me with, that have I done,/And more, much more" (5.3.152-3)-and amendment:

I pant for life. Some good I mean to do,

Despite of mine own nature. Quickly send -

Be brief in it - to th' castle; for my writ

Is on the life of Lear and on Cordelia. (5.3.217-20)

These three-contrition, confession, and amendment-were required for true repentance in the formulations of Aquinas and Calvin, leading the audience to sympathize with him, as they do with the beaten Lee at the end of the postmodern play. Edmund shows, indeed, a flicker of repentance for his

29. Tucker Orbison has also suggested that "Lee and Austin form dual opposed elements in a single self," with Lee functioning as a Jungian "shadow figure" for Austin (Tucker Orbison, "Mythic Levels in Sam Shepard's True West," Modern Drama 27 no. 4 (1984): 513). See also, David Wyatt, "Shepard's Split," South Atlantic Quarterly 91 no. 2 (Spring 1992).

30. Jacques Derrida, Positions, trans. Alan Bass (London: Athlone, 1981), 41; \& _ Spurs: Nietzsche's Styles (Chicago: University of Chicago, 1978), 81. 
villainy and admits to having ordered Cordelia's death. His peculiar change, scarce among Shakespeare's villains, is enough to make the audience wonder if Edmund's villainy sprung from his illegitimacy or simply from a misdirected desire for a familial love. Literally, representations, beliefs, and customs fail to be workable.

Lee who is a thief does not have a good position either; his remoteness from home and his mother, as explained above, is a clue to his status as an ostracized child. Shakespeare and Shepard seemingly are digging out the roots of power ambitions. According to Richard Matthews, Edmund is actually like Lear, someone who suffers and creates suffering. ${ }^{31}$ Lee also at the beginning of the play in a troublemaking way imposed himself on Austin, but at the end he was injured. Although it should be mentioned that in contrast to Edmund who changes suddenly, Lee's forward move through the play is continuous; Austin also casts his skin, but Edgar never.

In a little-noted ironic twist to the play, while the illegitimate Edmund is ultimately foiled in his efforts to have land, Edgar, who in both law and custom has no legitimate claim to the throne of Britain and is not even of the highest rank of nobility, winds up sovereign of all the land, the country. ${ }^{32}$ Austin, on the other side, at least apparently, is an author and likes to have his script played, but suddenly Lee claims his position, and fortune smiles on him. The former does everything to keep Lee out of the house or his territory: he lends him his car and tells him to forget about its tank full of gas (1372; 1.2.), yet in the words of Terry Eagleton, "the deathly emptiness of the dispossessed is the only source from which a more jubilant, self-delighting existence can ultimately spring." ${ }^{33}$ Lee, here, is the literal translation of "the dispossessed" who through his lively spirit revolutionizes everything.

\section{Conclusion}

In this paper, the effort was made to exhibit the similarities in the light of differences between the two brothers in The Tragedy of King Lear and True West. As was evidenced, even fully-developed characters could be considered as "types" who frequently appear throughout the history of literature. Indeed, according to Lukacs "typicality is a quality combining uniquely individualized with historically representative features." 34 The study's examples prove the fact that literature is "universal," as it is created by humans, who the world

31. Kahan, King Lear: New Critical Essays, 52.

32. Loomba, \& Orkin, Post-Colonial Shakespeares, 210.

33. Ewan Fernie, Spiritual Shakespeares (Abingdon: Routledge, 2005), 17.

34. Chris Baldick, The Concise Oxford Dictionary of Literary Terms (Oxford: Oxford University Press, 2004), 256. 
like the good and dislike the bad. This concept of universality was based on a Derridean reading which neither disavows individuals' specificities, nor neglects details in history. In practical terms, if a totally different writer in gender, race, religion, and nationality calls for, say, freedom, the artistic creation will not only be counted as a personal record since freedom as a value is what human kind has fought for throughout history; in essence, although a private experience, it is a common concept among men. Simply put, as already mentioned, at the end of the plays, according to a comparative study, Lee and Edgar, who were primarily opposites, turned out to be a similar pair to compare. In this way, the claim could be made that in comparative studies "alterity" should be taken into consideration; otherwise, in regard to human nature and the typicality of all characters, which Lukacs asserts, a comparative study predicated only on similarities is a superficial reading.

\section{Bibliography}

Attridge, Derek. "Introduction: Derrida and the Questioning of Literature." Introduction to Acts of Literature. Ed. Jacques Derrida. New York: Routledge, 1992.

Baldick, Chris. The Concise Oxford Dictionary of Literary Terms. Oxford: Oxford University Press, 2004.

Bottoms, Stephen James. The Theatre of Sam Shepard: States of Crisis. Cambridge: Cambridge University Press, 2000.

Bloom, Harold. Sam Shepard. New York: Infobase, 2009.

Bloom, Harold. William Shakespeare's King Lear: Bloom's Notes. Chelsea: Chelsea, 1996.

Callens, Johan. Sam Shepard: Between the Margin and the Centre. Amsterdam: Overseas, 1998.

Coleridge, Samuel Taylor. "Notes on King Lear" (1819). Literary Remains. Edited by Henry Nelson Coleridge. Vol. 2. London: Pickering, 1836.

Corrigan, Paul. Shakespeare on Management: Leadership Lessons for Today's Managers. London: Kogan Page, 1999.

Derrida, Jacques. Acts of Literature. Edited by Derek Attridge. New York: Routledge, 1992.

Derrida, Jacques. Limited Inc. Translated by Samuel Weber and Jeffrey Mehlman. Evanston: Northwestern UP, 1988.

Derrida, Jacques. Positions. Translated by Alan Bass. London: Athlone, 1981.

Derrida, Jacques. Spurs: Nietzsche's Styles. Chicago: University of Chicago, 1978. 
Dollimore, Jonathan. Radical Tragedy: Religion, Ideology and Power in the Drama of Shakespeare and His Contemporaries. Brighton: Harvester Wheatsheaf, 1984.

Fernie, Ewan. Spiritual Shakespeares. Abingdon: Routledge, 2005.

Hawkes, David. Ideology, 2nd ed. London: Routledge, 2003.

Kahan, Jeffrey. King Lear: New Critical Essays. New York: Routledge, 2008.

Kleb, William. "Worse than Being Homeless: True West and the Divided Self." In American Dreams: The Imagination of Sam Shepard. Edited by Bonnie Marranca. New York: Performing Arts Journal, 1981.

Loomba, Ania, \& Orkin, Martin. Post-Colonial Shakespeares. London: Routledge, 2004.

Machiavelli, Nicolo. The Prince. Translated by W. K. Marriott. Coral World Greatest Books, 1991.

McEvoy, Sean. Shakespeare: The Basics. London: Routledge, 2000.

Morris, William. The American Heritage Dictionary. Boston: Houghton, 1972.

Orbison, Tucker. "Mythic Levels in Sam Shepard's True West." Modern Drama 27 no. 4 (1984).

Roudan'e, Matthew. The Cambridge Companion to Sam Shepard. Cambridge: Cambridge University Press, 2002.

Shakespeare, William. The Tragedy of King Lear. Edited by Jay L. Halio. Cambridge: Cambridge University Press, 2005.

Shepard, Sam. True West. The Bedford Introduction to Drama. Edited by Lee A. Jacobus. New York: St. Martin's, 2001.

Wyatt, David. "Shepard's Split." South Atlantic Quarterly 91 no. 2 (Spring 1992). 